\title{
Reservoir Characteristics researching in Gulong oilfield Putaohua
}

\author{
reservoir \\ Yuechao Teng ${ }^{1}$, Haifeng Chen ${ }^{1}$, Haiqiang $\mathrm{Hou}^{1}$ \\ 1 Northeast Petroleum University The formation mechanism of oil and gas reservoir and resource evaluation \\ Heilongjiang Province key laboratory, Daqing, Heilongjiang, China, 163318
}

\begin{abstract}
The reservoir characteristics such as petrological and physical property characteristics of reservoir is the basic attribution of oil reservoirs, it directly controls the reservoir space, which influences the flow of oil and gas in reservoir thus reserve volume and production of oil, is one of the foundations of oil development. By counting and analyzing of diaphragm observing and physical properties data, the petrological and physical property characteristics of reservoir can be defined, and defining the stage of diagenic metamorphism by studying the transform of clay minerals, and then summarize and analyze the controlling factors of physical properties of the reservoir.
\end{abstract}

Key words: - Gulong oilfield; Putaohua reservoir; Controlling factors; Reservoir characteristics

\section{GENERAL GEOLOGY OF STUDYING AREA}

Gulong oilfield located in Heilongjiang Province Daqing City Datong District and Taikang County, south to Datong District Shuangyushu and Bajingzi, north to Xingshugang west to Aobaota and east to Xinglongquan. The main oil producing reservoir of the block is Putaohua, The main type of reservoirs is lithologic deposit, followed by structural - lithologic system. Putaohua has favorable conditions such as shallow depth, relatively better physical properties, higher oil and gas production, is a focus block of exploration and development in northern Songliao Basin ${ }^{[1]}$.

Gulong oilfield is main located in a secondary structural unit Qijia - Gulong sag in the middle of the Songliao Basin, was nearly north-south long strip distribution of deep-water basin of long-term succession ${ }^{[2]}$. Tectonic style of the area orders Talaha syncline and Changjiaweizi syncline as the center, the tectonic shape of the area is a half-syncline structure, two synclines and two nosing structures under the background of terraces. Combined with sandstone thickness, sandstone-layer ratio, sandstone body distribution direction, mudstone color, lithology and grain grade analysis, the study area Putaohua reservoir is a delta front subfacies controlled by the northern and western sedimentary provenance. Yaojial group had a slowed down sedimentation rate during the entire sedimentary period in the basin, was in a process of significant filling period in the total depression period $^{[3]}$, the two provenance are abundant in supplying detrital material, the lake basin is lifted and blockage shallowing, sand body totally performances the feature of the east thinner while the west thicker, and the south thinner while the north thicker.

\section{PETROLOGY CHARACTERISTICS OF THE RESERVOIR}

The sand body in the reservoir of Gulong oilfield is mainly delta front sand body, is relatively developed, is a positive rhythmic layer. Executing a statistical analysis on grain grade of rock samples in the studying area. The diameters of grain size are smaller than $0.32 \mathrm{~mm}$ in region of interest, mainly distributed 
between $0.05 \mathrm{~mm}-0.25 \mathrm{~mm}$. According to fragmental rock grain grading standards, the lithology of studying area is of most fine sandstone, silty fine sandstone, fine silty sandstone, but mainly fine sandstone (Fig.1).

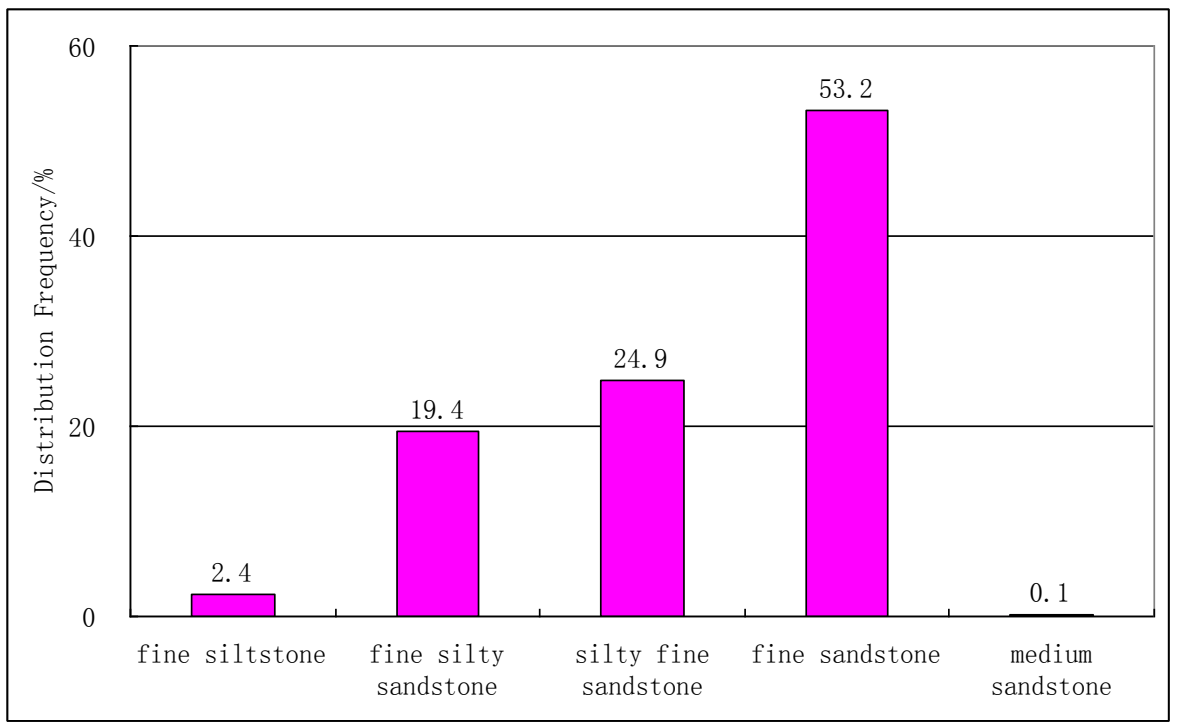

Fig.1 Histogram of petrology distribution in Gulong oilfield Putaohua reservoir

Executing identification on diaphragm of rock samples in the study area, the analysis reveals the type of minerals contained in the study area and its percentage (Table 1). In clastic constituents, quartz takes up about $17 \%-42 \%$, with an average of $24.5 \%$; feldspar take up about $18 \%-45 \%$, with an average of $33 \%$, and mainly made up with orthoclase and plagioclase, almost free of micro-plagioclase, the degree of weathering of feldspar is mainly moderate, followed moderate-deep; and cuttings have a higher content as $6 \%-55 \%$, with an average of about $21.7 \%$, the main component of cuttings is magmatic rock, metamorphic and sedimentary rocks are relatively rare.

The interstitial material of sandstone is mainly carbonate cement and clay minerals. The common clay minerals in cements are mainly illite, chlorite and illite/smectite clay; and to carbonate is mainly calcite ${ }^{[4]}$. Sandstone detrital sorting is mainly good - moderate, the main psephicity is subrounded, partly for hypocone-subrounded; between particles are often point and line contact, in particulate support structure; cementation type is mainly pore cementation, a part of sandstone due to the high cement content showed substrate cementation, sandstone in some areas due to chemical pressolution showed mosaic cement, indicating more strongly degree of compaction in the area. Based on analysis above, the textural maturity of sandstone in this area is relatively low, while the structural maturity is good-medium ${ }^{[5]}$.

Table 1 Table of mineralogical component identification in Gulong oilfield

\begin{tabular}{|c|c|c|c|c|c|c|c|c|c|c|}
\hline \multirow[b]{3}{*}{ Value $(\%)$} & \multicolumn{7}{|c|}{ Clast Part $\%$} & \multicolumn{3}{|c|}{ Cement Part \% } \\
\hline & \multirow[b]{2}{*}{ Quartz } & \multicolumn{3}{|c|}{ Feldspar } & \multicolumn{3}{|c|}{ Rock Clast } & \multirow[b]{2}{*}{ Shale } & \multirow[b]{2}{*}{ Siderite } & \multirow[b]{2}{*}{$\begin{array}{c}\text { Calcit } \\
\mathrm{e}\end{array}$} \\
\hline & & $\begin{array}{l}\text { Ortho } \\
\text { clase }\end{array}$ & $\begin{array}{c}\text { Aman } \\
\text { zonst } \\
\text { one }\end{array}$ & $\begin{array}{c}\text { Plagio } \\
\text { clase }\end{array}$ & $\begin{array}{c}\text { Magma } \\
\text { tic } \\
\text { Rock }\end{array}$ & $\begin{array}{c}\text { Metamorp } \\
\text { hic } \\
\text { Rock }\end{array}$ & $\begin{array}{l}\text { Sedimen } \\
\text { tary } \\
\text { Rock }\end{array}$ & & & \\
\hline Minimum & 17 & 18 & 0 & 1 & 6 & 0 & 0 & 1 & 0 & 1 \\
\hline Maximal & 42 & 45 & 1 & 8 & 55 & 5 & 10 & 25 & 16 & 44 \\
\hline Average & 24.5 & 29.5 & 0.1 & 3.4 & 21.5 & 0.1 & 0.1 & 12.8 & 0.1 & 7.9 \\
\hline
\end{tabular}




\section{PHYSICAL PROPERTY CHARACTERISTICS OF THE RESERVOIR}

Porosity and permeability are important properties which reflect characteristics of reservoir, so based on existing data in the researching area, conducted porosity, permeability statistics to provide sufficient evidences for a more accurate reveal of reservoir properties and distribution rules. The model of reservoir parameters establishing acquirement relies mainly on core sample analysis data. The exploration wells for statistics in reservoir characteristics have a relatively homogeneous distribution in the region, which have a better representation.

\section{A. Effective porosity}

Effective porosity is one of the important properties reflect reservoir characteristics, effective porosity refers to the ratio of volume of pore space in the rock sample communicate with each other to the total volume of rock sample. By analyzing core porosity data in the studying area, effective porosity reservoir distribution histograms is established (Fig.2), effective porosity of the reservoir are mainly distributed between 6-21\%, with an average of $15 \%$, according to the China National Petroleum Corporation Company Reservoir Evaluation Method Specification ${ }^{[6]}$ (SY/T 6258-1997), reservoir of the studying area belongs to moderate-low porosity reservoir.

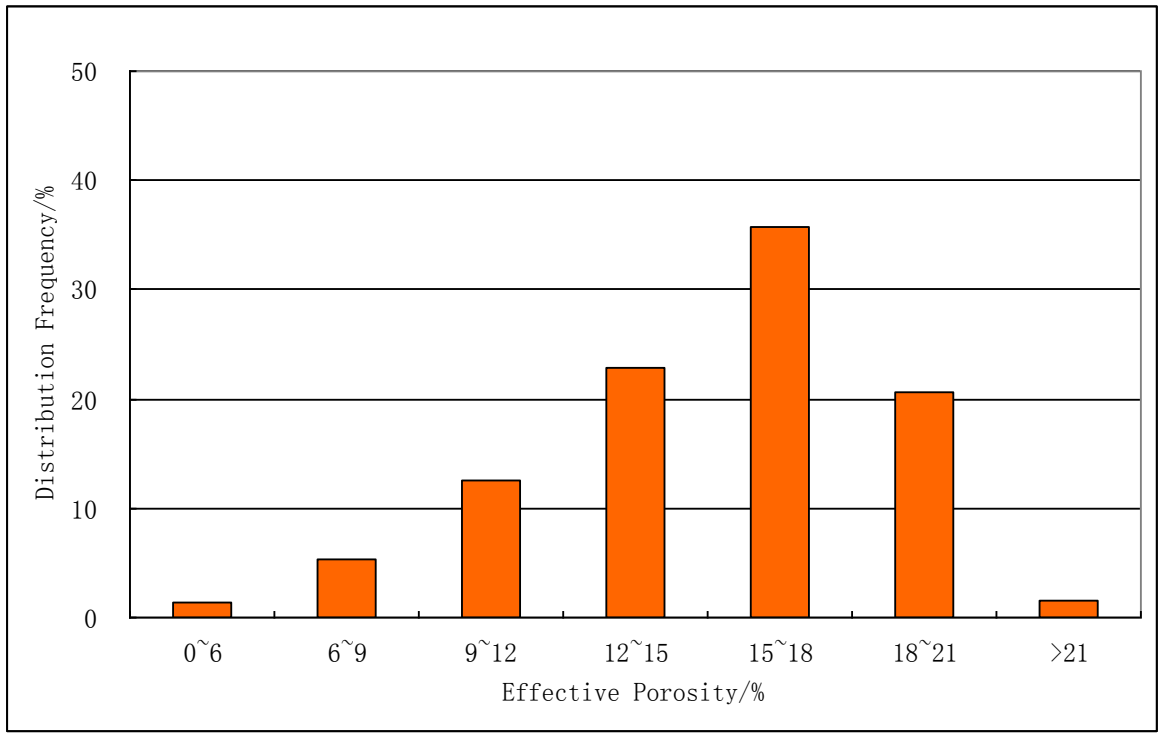

Fig.2 Histogram of effective porosity distribution in Gulong oilfield Putaohua reservoir

\section{B. Coefficient of permeability}

Coefficient of permeability can be used to assess reservoir quality and reservoir heterogeneity, which of great significance for the characterization of reservoir properties. Under the condition of pressure differential, the property that rock allows the fluid flows through is named permeability, the measurement of the patency of a certain viscosity fluid flow through the formation is named coefficient of permeability. By analyzing core coefficient of permeability data in the studying area, coefficient of permeability reservoir distribution histograms is established (Fig.3), coefficient of permeability of the reservoir are mainly distributed between $0.01 \mathrm{mD}-200 \mathrm{mD}$, with an average of of $16.3 \mathrm{mD}$, according to the China National Petroleum Corporation Company Reservoir Evaluation Method Specification(SY/T 6258-1997), reservoir of the studying area belongs to low-especially low permeability reservoirs. 


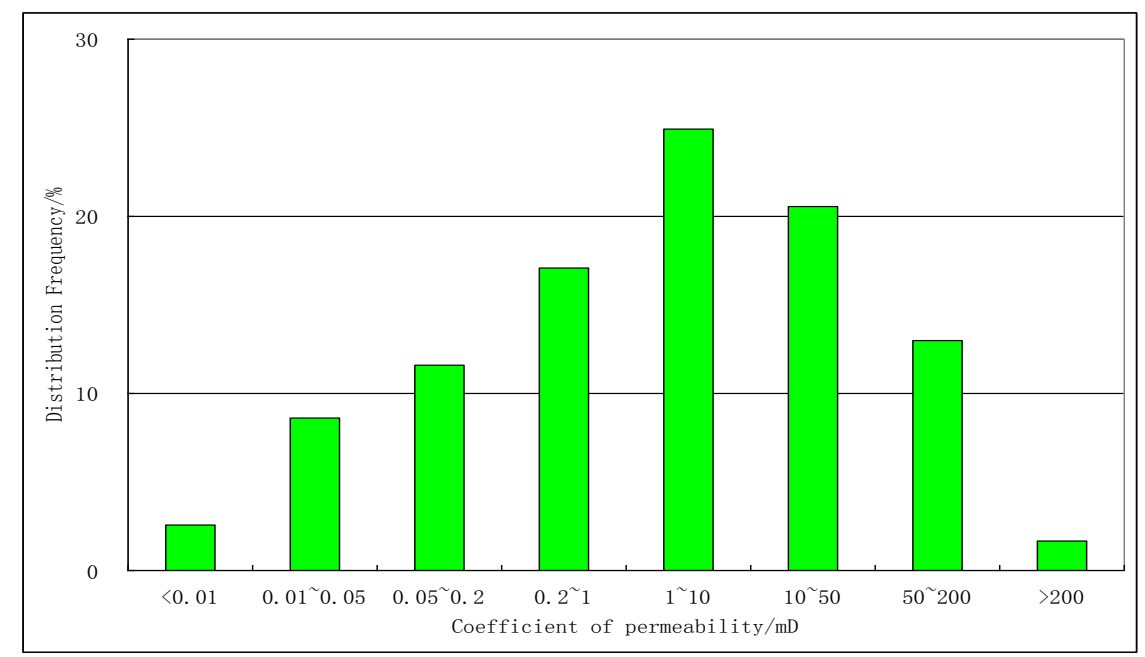

Fig.3 Histogram of Coefficient of permeability distribution in Gulong oilfield Putaohua reservoir

\section{CLAY MINERAL TRANSFORMATION}

Diagenesis refers to the physical and chemical changes in the burial environment until metamorphism, after the sediments were deposited and before consolidation occurs. Diagenesis directly transforms the reservoir space underground, and thus reflects on reservoir characteristics. This paper determines diagenesis stage of Gulong oilfield by studying clay mineral transformation.

A. General characteristics of clay mineral transformation

The diagenesis of shale mainly shows in the evolution of variety of kinds of clay minerals with depth. Clay minerals of Gulong oilfield shale are mianly smectite, illite, illite/smectite mixed layer, followed by chlorite and kaolinite, mainly less than $20 \%$. Smectite mainly appears above $1600 \mathrm{~m}$, disappears below $1800 \mathrm{~m}$ on the whole. Illite content increases with depth increasing, illite/smectite mixed layer decreases with increasing depth after the first increase, which is the result of the illitization of smectite and kaolinite ${ }^{[7]}$.

In the process of smectite transformation, the released $\mathrm{Si}^{4+}$ can contribute to the generation of kaolinite and authigenetic growth of quartz debris in shallow sandstone ${ }^{[8]}, \mathrm{Ca}^{2+}$ can form early calcite cement. At conditions with a higher temperature, $\mathrm{Fe}^{2+}$ and $\mathrm{Mg}^{2+}$ released by the illitization of smectite, starts the generation of iron calcite and iron ankerite, $\mathrm{Fe}^{2+}$ and $\mathrm{Mg}^{2+}$ react with kaolinite is able to generate chlorite in the depths ${ }^{[9]}$. (Fig.4).

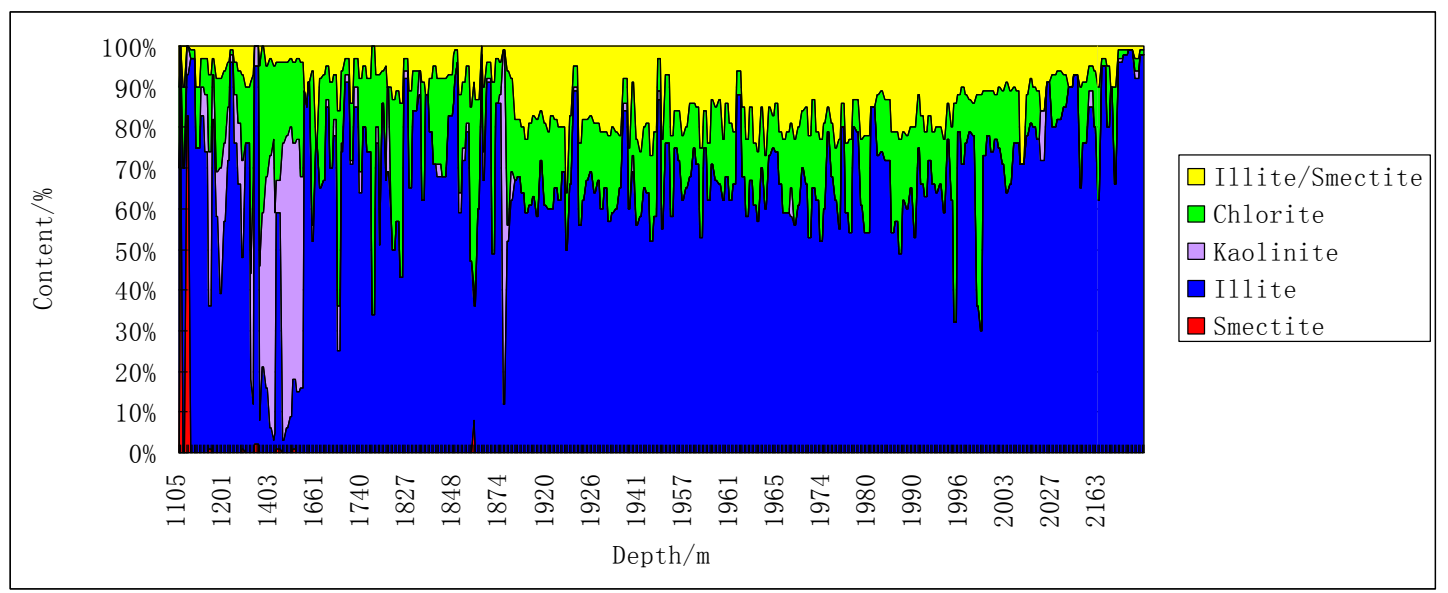

Fig.4 Vertical distribution of clay of shale in Gulong oilfield 


\section{B. Dehydration of clay minerals and their geological significance}

In the process of diagenesis, the process of conversion from smectite to illite and from kaolinite to chlorite and chlorite can release $\mathrm{H}^{+}$. When $\mathrm{H}^{+}$enter into the pores of the rock, mixed with formation fluid, then becomes acid thermal fluid to dissolute reservoir, resulting in secondary porosity. Ying Fengxiang et al (2004) in the study of illitization of smectite in eastern Biyang, Dongying, Liaodong sunken, combine illite/smectite mineral transformation with dehydration characteristicsc, divided it into five bands ${ }^{[10]}$ (Fig.5):

a. Smectite band: The band comprises dispersing smectite. Smectite layer occupies more than $80 \%$ in the illite/smectite layer. In this area pore water is mainly dehydrated, its formation temperature is $50^{\circ} \mathrm{C}$, belongs to the early diagenetic A period.

b. Gradient zones: Smectite begins to transformation mixed layer. Smectite layer occupies $80 \%$ to $60 \%$ in the illite/smectite layer, iron calcite and quartz secondary growth appear, its formation temperature is $60{ }^{\circ} \mathrm{C} \sim 70{ }^{\circ} \mathrm{C}$, belongs to the early diagenetic $\mathrm{B}$ period, is a interlayer water stability zone.

c. The first rapid transformation band: smectite only occupies $60 \%$ to $40 \%$. Smectite has clearly transformed to the mixed layer while it is a band of first interlayer water dehydrates, belongs to the middle diagenetic $\mathrm{A}_{1}$ sub-period.

d. The second rapid transformation band: Smectite had a large transformation to illite/smectite layer, only about $20 \%$ of smectite left, is a band of first interlayer water rapid dehydrates, and organicr has matured, belongs to the middle diagenetic $\mathrm{A}_{2}$ sub-period.

e. The third transformation band: smectite occupies less than $20 \%$, is a super-lattice, belongs to the middle diagenetic $\mathrm{B}$ period.

As seen above, in the precess of transformation from smectite to illites, there are two phases that interlayer water dehydrates, they respectively correspond the first

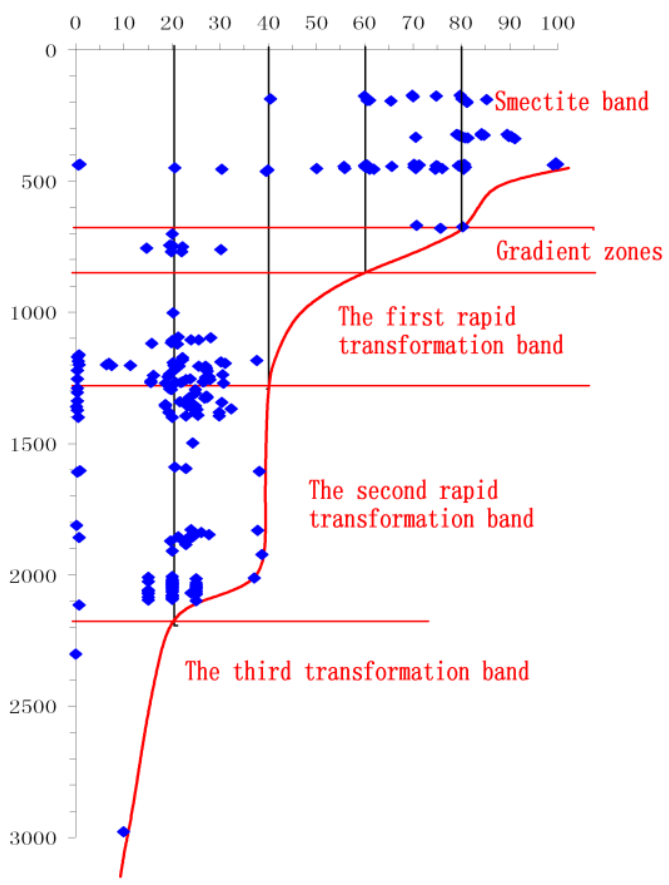

Fig.5 Vertical evolution of $\mathrm{S} \%$ in $\mathrm{S} / \mathrm{I}$ of shale in Gulong oilfield and second rapid transformation band, they all correspond to a large release of $\mathrm{H}^{+}$. The depth range of massive release of $\mathrm{H}^{+}$in Gulong oilfield is approximately $850 \mathrm{~m} \sim 2200 \mathrm{~m}$. Within this depth range, the transformation of clay mineral releases $\mathrm{H}^{+}$, forms of acidic water, dissoluting unstable mineral in the formation, resulting in secondary porosity generation, is an important factor of the generation of secondary porosity in reservoir of the studying area during the middle diagenetic $\mathrm{A}_{1}-\mathrm{A}_{2}$ sub-period.

Fig.5 shows that Putaohua reaervoir mostly places in the second rapid transformation band with a small part in the first rapid transformation band, belongs to the middle diagenetic $\mathrm{A}_{1}-\mathrm{A}_{2}$ sub-period. Certificate that the target layer existing a large number of hydrogen ions released to produce acidic water, resulted in a stronger dissolution, is more favorable for the development of secondary porosity.

\section{THE ANALYSIS FOR FACTORS CONTROLLING PHYSICAL PROPERTIES OF RESERVOIR}

This study is based on the results of identification for grain grade of the rock samples, conducting comprehensive analysis combined with data such as effective porosity and coefficient of permeability, this paper 
believes that the controlling factors for physical properties of reservoir are mainly lithology, sedimentary environment and diagenesis.

A. Lithology is the main controlling factor influences physical properties of the reservoir

The influence of lithology of the study area on the effective porosity is not large, effective porosity ranged from $9 \%-21 \%$. For coefficient of permeability, the influence is very large, for the different lithology, coefficient of permeability makes a difference for five orders of magnitude difference. This shows that the grain grade of the reservoir have a certain influence on porosity, while a strong control action on coefficient of permeability.

B. Sedimentary environment has a strong control action on reservoir properties

Contrast the effective porosity and coefficient of permeability with sandstone thickness data can be seen, the physical properties and characteristics of the reservoir are in accordance with sandstone distribution with that place large sandstone thickness, reservoir quality is good, otherwise poor. Analyze on effective porosity and coefficient of permeability data of various wells evenly distributed in the studying area. Easy to know reservoir properties of syncline is significantly poorer in the reservoir of interest of the study area, while nose structure on provenance direction and slope have good physical properties.

C. Diagenetisis has a relatively strong control action on physical properties of reservoir

By studying the conversion for clay minerals, diagenesis in the study area is diagenetic A period can be known. The most important diagenetisis in research area is dissolution, secondary porosity is reletavely developed. In this way, the diagenetic of the studying area transforms the underground reservoir space, thus affecting the physical properties of the reservoir.

\section{CONCLUSIONS}

A. Gulong oilfield Putaohua reservoir have characteristics of low compositional maturity, high structural maturity, high mud content, which belongs to moderate-low porosity and low-especially low permeability reservoirs.

B. Putaohua reaervoir mostly places in the second rapid transformation band with a small part in the first rapid transformation band, belongs to the middle diagenetic A sub-period. resulted in a stronger dissolution, is relatively favorable for the development of secondary porosity.

C. The controlling factors for physical properties of Gulong oilfield Putaohua reservoir are mainly lithology, sedimentary environment and diagenesis. Lithology is the main factor which affects the characteristics of the reservoir, sedimentary environment and diagenesis have some control on the characteristics of the reservoir.

\section{REFERENCES}

[1] Yang Yufeng. Formation and distribution of lithologic pools in Songliao basin [J]. Oil\&Gas Geology.2004, 25(4):393-399.

[2] Gao Ruiqi, Cai Xiyuan. Formation conditions and distribution law of Songliao Basin oil and gas fields [M].Beijing: Petroleum Industry Press,1997:50-52.

[3] Chan Jingfu,Ji Youliang. Controlling factors for the heterogeneity of the Putaohua oil reservoirs in the Daqing Oil Field [J]. Sedimentary Geology and Tethyan Geology,2006,26(4):95-99.

[4] Fan Xu, Xu Yunting, Dong Zhonglin et al. General reservoir beds features of Putaohua oil reservoir in Songfangtun oilfield,Songliao basin [J]. Journal of Daqing Petroleum Institute, 1999,23(3):70-73.

[5] Wang Yachun,Shi Rong,Ma Chengdou et al. Reservoir classification of Putaohua oil layer in the south of Aobaota Oilfield[J]. Journal of Daqing Petroleum Institute,2007,31(4):10-12.

[6] SY/T 6258-1997, China National Petroleum Corporation oil and gas reservoir evaluation methods [S]. 
[7] Giles M R and J D. Marshall. Constraints on the development of secondary porosity in the subsurface-re-evaluation of process. Marine and Petroleum Geology, 1986, 3: 243-255.

[8] Boles J R G, Franks S G. Clay diagenesis in Wilcox Sandstones our. Sed. Petrol., 1979: 49.

[9] Zheng Junmao, Pang Ming. Research on diagenesis on clastic sedimentary [M]. Wuhan:Chinese Geology University Press, 1989

[10] Ying Fengxiang,He Dongbo,Long Yumei et al.SY/T5477-2003. People's Republic of China oil and gas industry standards and clastic diagenetic stage division.Beijing: Petroleum Industry Press,2003. 